\title{
SYSTEM ANALYSIS OF THE FUTURE EDUCATORS' PSYCHOLOGICAL AND PEDAGOGICAL TRAINING EXPERIENCE
}

\author{
NATALIYA Tytova, OKSANA KATSERO, OKSANA KONDUR
}

\begin{abstract}
It is established that the integration of the higher education of Ukraine to the European educational space is connected to the problems of vocational education system reformation in order with the international requirements. It was determined that an effective way to implement the requirements to the future specialists' professional qualities is to diversify their professional training as well as to create and provide conditions for a positive synergy with the aim to ensure scientific character, conformity to culture, fundamentals, humanization, consistency, innovation, accessibility, unity and accessibility, continuity and diversity training for applicants.

The research work deals with the terminological aspects of future specialists' psychological and pedagogical training in higher education institutions. The essential analysis of vocational training teachers' psychological and pedagogical training is based on the unity of pedagogical theory and practice and considers contextual education and upbringing, based on the laws and mechanisms of pedagogical creativity.

The analysis of scientific works, published up till now by domestic and foreign researchers, made us come to the conclusions that one of the reasons for the backwardness of the students' psychological and pedagogical training is a low level of pedagogical science development, inflexibility of educational programs, fragmented courses, lack of practical orientation. Development of requirements for the training of vocational teachers, with sectorial and integrated psychological and pedagogical components, is a priority now. The main task of higher vocational education is to prepare teachers who are ready for the organization and implementation of fundamental, technical and vocational training in practice at all levels of vocational education: vocational schools, technical schools, colleges, professional lyceums and gymnasiums, etc.

The research work analyzes the terminology and clarifies the concepts "training", "vocational teacher training", "general pedagogical training" and "psycho-pedagogical training of future specialists in pedagogical institutions".
\end{abstract}

Keywords: psychological and pedagogical training, professional educators, higher education, vocational education.

\section{INTRODUCTION}

The transformation of the higher pedagogical education is motivated by the education system structure modernization in Ukraine and necessity of its integration into European and world educational space. Implementation strategy of this task involves detailed analysis of available 
experience of previous generations, and its adaptation to new, innovative, advanced learning technologies oriented on the further positive synergies. The integration of the teachers' education system lies in its quality. The provision of quality psychological and pedagogical training of vocational training teachers is a pedagogical problem. In addition, without solving this problem it is impossible to provide high-quality professional training of the future specialists in the education sphere and to ensure the development of competitive national system of higher education.

The initiated analysis of the recent researches and publications is supposed to solve this problem. Progressive ways of vocational training teachers' psychological and pedagogical training modernization are currently a very urgent direction in modern vocational education development and the object of many domestic and foreign scholars' researches. Meanwhile, the research system of vocational training teachers' psychological and pedagogical training hardly carries out all the existing specializations (profiles).

The goal of the article lies in theoretical and methodological analysis of vocational education teachers' psychological and pedagogical training to justify its nature and key categories' formation.

\section{ANALysis AND Discussion}

Scientific and theoretical basis for the justification of modern approaches in vocational training teachers' psychological and pedagogical training implementation became philosophical, methodological, pedagogical and psychological basis in the sphere of higher pedagogical education (which is mantioned in the works of V. Andrushchenko, N. Demyanenko, V. Kremen, M. Korets, P. Pakeistas, N. Protassova, City of Seleucus, V. Sidorenko, D. Korzhevskogo and others), in the sphere of professional education (which is represented in the researches of S. Batyshev, A. Belyaeva, N. Bryukhanova, V. Bezrukova, A. Dubbink There. Sera, A. Kovalenko, V. Flint, From. Kurland, V. Lozovetska, N. Have nichkalo, V. Radkevich, A. Shcherbakov and others).

Methodological areas of future specialists' professional training research in the sphere of professional education are represented in scientific works of I. Bender, R. Gurevich, G. Gorbatyuk, I. Bankovskogo, A. Litvin and N. Manuka, A. Markov, V. Mozgovoy, L. Tarhan and many others.

According to the "Encyclopedia of professional education" under the edition of S. Batyshev, training is seen to be "a body of special knowledge, skills, qualities, work experience and behavior rules that ensure the possibility to reach success in a particular profession. Depending on the skill level and complexity, profession training includes secondary, lower (vocational) or higher education" [21, p. 3]. Fundamentally, a philosophical interpretation of V. Andrushchenko as a co-author of the document "Pedagogical Constitution of Europe" emphasizes "the unification of the educational processes, which occur in modern Europe, is to encourage the search for general principles of the complex professional training of teachers. Pedagogical Constitution of Europe provides a definition of a single value and methodological platform to prepare a new teacher for United Europe of the XXI century". [2, p. 7].

Exploring the theoretical and methodological bases of didactic competence formation of future teachers of engineering, L. Tarhan notes that the main professional requirements of a competent teacher of engineering are associated with mastering the skill-oriented design of the training cycle, namely, design description of training objectives, selection exercises, adequate for these indicators, the choice of teaching methods and its usage sequence, definition of the parameters required to receive information on the development progress of the subjects studied, the correction of mastering process and evaluation of the results. According to the researcher, the theoretical readiness of the vocational training teacher is evident in his activities, in a generalized ability to think in a pedagogical way, in the presence of analytical, predictive, design skills and reflection.

As L. Tarhan said, that the cross-cutting component of training is a formation of professional competence methodological bases, which has the following components: social, psycho-pedagogical, didactic, special, methodological, informational, management, cultural, communication, research, and reflective. 
The aim and result of education is to transform the didactic competence of future teachers of engineering. L. Tarhan outlines the list of necessary professional knowledge, skills and professional qualities expedient to train the future teachers of engineering in the HEF educational process. The researcher believes that the didactic competence of teachers of engineering is a critical component in the overall training system for future vocational and educational activities, methodological basis for the planning and design of educational and scientific processes in HEF engineering science education. According to L. Tarhan, interaction and interpenetration of the educational and engineering components in engineering-pedagogical education is most effectively revealed in didactic activities, which aims to transform the engineering knowledge in order to solve didactic problems.

Ensurance of the integrity of the didactic competence content and structure in the training framework allowed the researchers to highlight the professional pedagogical unit discipline, so-called "competence core". The main goal of the discipline is to form the didactic competence of future teachers of engineering, which is consistent with the competence-active approach in training, as far as it has theoretical and practical forms of expression. It contributed to the selection and implementation of the best variant of each component of the educational process, namely, the optimal selection of the content, forms and methods, technologies and training tools, functional activities, forms of selfdevelopment realization [17, p. 18-20].

We share the position G. Romantsev on the interpretation of teacher's professional training. Professional educator is creative and innovative. He covers the labor market research, enterprise peculiarities and development prospects (regional enterprises), on the basis of which he is able to create projects, semantic blocks of educational process (professional characteristics of the employee, training and software documentation, etc.) and the procedural units (individualized, focused on a future career, and comprehensive didactic means). In addition, the activities of this specialist involves the implementation of his own educational methods, organization and realization of educational process in the secondary school sphere, based on the concept of industrial education and productive labor combination, with the active application of advanced industrial technologies [19, p. 11]. "Psychopedagogical training is a kind of psychological and pedagogical education of the individual, aimed at developing the psycho-pedagogical competences and ensuring the experts' orientation at professional development, creative potential development, personal growth and so on" [8, p. 9].

Exploring the aspects of the primary school teachers' professional and pedagogical training, L. Khomich, found that this kind of training "is the process of teaching the psycho-pedagogical disciplines to students while doing academic and research work. All the disciplines of the psychopedagogical cycle, combined together, will determine the professional orientation of pedagogical institutions, to be at the core of students' professional training" [20, p. 3].

According to V. Garden, future educators' professional and pedagogical training, "is an integrative holistic system, which is characterized by internal unity of components focused on the achievement of certain strategic goals of pedagogical education, disclosure of internal personality potential for future pedagogical activity" [16, p. 36].

According to A. Abdullina, professional-pedagogical preparation of the teacher in pedagogical higher education institution is a multi-faceted system, which integrates relatively independent, but interrelated and interdependent training system: socio-political, scientific, psychological, pedagogical and cultural, the main point of which is general pedagogical training [1, p. 24].

Authors in the article [22] deals with the problem of professional training of future teachers in Pavol Jozef Šafárik University in Košice (Slovak Republic). The authors found that the psychological and pedagogical component of the content is half the total volume of training.

Scientific interests of N. Demyanenko lie in the sphere of general pedagogical teacher training, the essence of which is "to achieve the unity of educational theory and practice, as well as cultural conformity, fundamentals and mobility of knowledge" [4, p. 13]. We believe that this definition is acceptable for the psycho-pedagogical training of future vocational training teachers.

The study based on the defined term "professional teacher training", suggested by the creative team headed by A. Boyko, interpretates the scientific and methodological support of this training as a 
focused, independent, orderly and controlled system of regulations, policies, plans, programs and guidelines, as well as "specific organizational and pedagogical conditions and means, united by a common concept of the individual teacher's creative personality in the conditions of multilevel education" [11, p. 3].

S. Vitvitska notes that teacher's education in the respective occupations for various educational stages covers the "fundamental psycho-pedagogical, methodological, informational, technological, practical and socio-humanitarian training" [5, p. 45]. However, justifying every kind of training, the scientist does not distinguish the terms "teacher's training" and "fundamental psycho-pedagogical training", namely, "educational preparation involves study, in addition to traditional academic disciplines (didactics, education theory, history of pedagogy, comparative pedagogy, basic pedagogical skills, modern educational technology and other disciplines based on profession features" [5, p. 45]. We agree that methodical training of a future teacher is cross-cutting and is interrelated with the psychopedagogical training, because it aims at learning the academic subject and extracurricular activity teaching methodology. This is done while studying the psychological and pedagogical disciplines, assignments, training, production (pedagogical) practices and regarding the methodological orientation on fundamental academic disciplines [5, p. 45].

G. Gorbatyuk defines the methodological training of vocational training educators as an integral component of their professional training, but, along with that he sees it as a "separate component, which is to ensure the integration of related scientific knowledge in the process of analysis and selection of learning paths, the justification of the principles, contents, methods and forms of learning in each specific situation. In the vocational training educators' training system it is necessary to use a unifying component that integrates all the blocks (cycles) into a single entity. That is called "monospecialty" [3, p. 129-130].

Regarding the definition of "psychological training", we have a few following interpretations of this term:

1. "Mental preparation - the system of psycho-pedagogical influence on the person to involve him into a specific activity" [15, p. 386];

2. "Individual psychological preparation for professional activity", which is defined as "the process of psychological readiness formation for productive participation in professional activities through a number of stages (information-semantic, diagnostic, remedial and developmental), providing the formation and development of psychological competence and psychological culture of the person" $[13$, p. 353].

Psychological readiness of the individual to the profession as the "education of complex multidimensional personality" and "the result of psychological preparation of the individual for professional activity" consists of the following components: "motivational (set of motivations in specialist's professional activity), cognitive (a set of psychological knowledge about the nature and patterns of professional activity), operational (a set of psychological skills to ensure the effective implementation of professional activities), personality (a set of professionally important qualities of the specialist personality)" [13, p. 353].

Exploring the system of continuous methodical training of future vocational training teachers, V. Kosyrev offers the following definition: "psycho-pedagogical training is a component of the integral process of future specialist identity formation in the system of professional education in higher education institutions, aimed primarily at the formation of professionally-pedagogical and social experience through the development of the system of psychological and pedagogical concepts, knowledge, skills and ways of action. Methodological training is the final stage of the integral process of the future specialist identity formation, a process that integrates social-humanitarian, naturalscientific, psychological-pedagogical, general professional and special (sectorial) training and is aimed at mastering the pedagogical activity technology" [9, p. 4].

A. Krivelyova explored the psychological and pedagogical training of future teachers of physics and mathematics in vocational education institutions and found out that "psychological and pedagogical training is the external influence on the internal state of the individual through the creation 
of corresponding organizational pedagogical conditions to achieve his optimal level of psychological and pedagogical competence" [10, p. 15]. The researcher also highlighted the internal and external psycho-pedagogical training of future vocational training teachers of physical and mathematical disciplines, namely, "an external psycho-pedagogical training is an organized educational process to create the conditions for students to achieve the optimal level of psychological and pedagogical competence, internal psycho-pedagogical training is the process of mastering the competencies defined in the achievement of the psycho-pedagogical competence, preconditions of formation which is to improve the performing basic professional functions corresponding to certain types of psychopedagogical activity" [10, p. 15].

We share this statement and offer the next graduation levels in the psycho-pedagogical training of vocational training teachers:

1) basic psychological-pedagogical training (general pedagogical), which involves learning the basics of didactics, psychology the history of pedagogy;

2) fundamental psychological and pedagogical training, which aims at the development of teachers' professional training in educational psychology, professional pedagogy and elective courses in psychopedagogical sphere (pedagogical image studies, professional mobility, etc.);

3) scientific psycho-pedagogical training, which involves some work on a coursework project on vocational training methods and diploma project;

4) functional psycho-pedagogical training, which requires students to learn techniques as applied discipline (professional education methods, educational work methodology, methodology of study groups and extracurricular activities, e-learning, etc.) and to implement the acquired knowledge in the process of teaching practice production;

5) creative psycho-pedagogical training of vocational training teachers, which is aimed at realization of creative projects, participation in Olympiads, competitions, etc., the result of which is the comprehensive qualifying examination [18].

So, our interpretation is the next one. Psycho-pedagogical training of vocational training teachers is a complex multilevel process of the future specialist's multifunctional activity in the field of vocational education, which results in formation of vocational training teacher's psychological and pedagogical readiness, manifested in the development of individual psychological and pedagogical education, individual psychological and pedagogical competence, individual psychological and pedagogical culture [18].

The content analysis of vocational training teachers' psychological and pedagogical training [12, 7, 14] showed that the diversity of professional-pedagogical education is not always fully reflected; and it is vital to fill it with modern trends in the teaching theory and practice with the aim to improve its quality.

Accordingly, the main content of the vocational training teacher's educational activity should be shared in ways of action in order to solve a class of problems aimed at mastering general ways of learning. In connection with this provision, the number of scientists, namely, V. Slastyonin, N. Tamarina, V. Burn, S. Spirin, G. Sarantsev, S. Yakushev, A. Mishchenko and others interpret the professional competence of teacher in the secondary professional education system through the next simulation: given the pedagogical activity structure and define it as a measure of activity impact in the pedagogical task solution.

It is also important to conduct research to identify attitudes of future professionals to professional ethics [23].

As L. Karavayev claims, "The prestige of the vocational training teacher is an ability to find creative problem solutions in a constantly changing environment, to satisfy and develop the educational necessities of applicants' education, self-education and self-improvement abilities. The formation of the profession prestige is possible not only through the subject-subject and subject-object activities, but also through the goals to create an independent design of one's own activities and its reflexive analysis. That is why, first of all, a teacher faces the task to direct his professional activity to rethink his own activities, structures and organization forms of students' activities [6, p. 183]. 
We share the idea of G. Romantsev about the training content in vocational and pedagogical education that needs to be built on the integration of psycho-pedagogical and industrial components. It is appropriate to emphasize that the methods of vocational education, which involves the intensification of future specialists' professional activity, focused on training students on future occupation, or rather training trade group to create working professionals. Thus, the emphasis is not on the academic subjects, but on the professional and qualification requirements for the worker of the relevant industry, which are embodied in the subject structure of the general professional and special curriculum cycles and fill every academic subject with content [19, p. 11].

According to scientific works of S. Batyshev the contents of engineering pedagogical education consists of the following blocks:

- general scientific and humanitarian training that contains a cycle of general disciplines;

- engineering and technical training;

- psycho-pedagogical training;

- production and technological preparation [21].

Based on the above and taking into account the necessity of vocational education and modernization in information technology development, the proposed structure of professional training teacher's psycho-pedagogical preparation, which is coordinated with competitive approach that underpins the Bologna process and the international European Commission Project "Harmonization of educational structures in Europe".

The structure of professional training teacher's psycho-pedagogical preparation consists of the next components: professional, invariant, variable and efficient. The generalized goal of the training is to form the vocational training teacher's psychological and pedagogical readiness, manifested in the development of special individual psychological and pedagogical professional competence.

The concept of "special psychological and pedagogical professional competence" is treated as a special set of qualities (professional handicraft, pedagogical skills, mentoring, motivation to the professional problem and situational task solution), aptitude (algorithmic, repetitive cyclical operations, professional score production processes), knowledge, and skills of psychological-pedagogical direction in accordance with the semantic purpose of professional environments in the types of economic activity and etiology of professional development, pedagogical, psychological and methodological effects of the educational process to modernize the system of vocational training teachers' professional training with transformational abilities" [18].

\section{CONCLUSIONS}

While evaluating the results of the previous research works produced in the field of vocational education in terms of the employers' requirements and the requirements of contemporary society to the future specialist, there is a reason to conclude that the psycho-pedagogical training of vocational training teachers involves development of the future specialist's ability to the mastery of pedagogical innovations and it is a decisive factor in the upcoming modernization of the vocational education system, and, consequently, in the sphere of education content update and the introduction of modern forms, means and methods of training.

We suggest, the structure of professional training teacher's psycho-pedagogical preparation consists of three main components, namely, invariant, variable, professional and efficient. The invariant component involves the study of normative disciplines of the vocational and practical training cycle and mastering students of two pedagogical practices (propedeutical and industrial) and course work on vocational training methodology. The variant component consists of two parts, which contains the disciplines chosen by HEF, and the disciplines of the students' free choice. The result component is a summary of the psychological and pedagogical preparation of future vocational training teachers, which takes into account the results of the examinations, reports on pedagogical and technological practices, and a comprehensive qualification exam, which is intended to check the level of readiness of students or graduates for their future professionalism in professional problem solutions. 


\section{REFERENCES}

[1] Abdullina A.O. General pedagogical training in the system of higher pedagogical education institutions. Prosveshchenie, Moscow, 1990. (in Russian)

[2] Andrushchenko V.P. Axiological platform of the modern educator's training. Visnyk Instytutu rozvytku dytyny. Seriia: Filosofiia, pedahohika, psykholohiia, 36 (2014), 5-8. Available at: http://nbuv.gov.ua/UJRN/Vird_2014_36_3 (in Ukrainian)

[3] Gorbatyuk R. Designing the psychological and pedagogical training of future vocational training teachers. Zbirnyk naukovykh prats Natsionalnoi akademii Derzhavnoi prykordonnoi sluzhby Ukrainy. Seriia: Pedahohichni nauky, 4 (2017), 123-134. Available at: http://nbuv.gov.ua/UJRN/znpnadpcpn_2017_4_12 (in Ukrainian)

[4] Demyanenko N.M. General pedagogical teacher training in the history of higher education of Ukraine (XIX - the first quarter of the XX century). Dissertation for the degree of Doctor of the Pedagogical Sciences: 13.00.04. Kyiv, 1999. (in Ukrainian)

[5] Vitvytska S.S. (Ed.) Innovative pedagogical technologies in the system of continuous professional education. POLISSIa, Zhytomyr, 2015. (in Ukrainian)

[6] Karavaeva L.P. The prestige of the vocational education teacher. In: The topical problem of pedagogy: materials of the International scientific conference. Publishing house "Young scientist", Chita, 2011, 181-184. Available at: https://moluch.ru/conf/ped/archive/20/1351/ (in Russian)

[7] Kovalenko A.E., Bryukhanova N.A., Melnichenko E.A. Theoretical basis of professional pedagogical training of future teachers of engineering in the context of Ukraine's accession to the Bologna process. Academy, Kharkiv, 2007. (in Ukrainian)

[8] The concept of the state target program of vocational education development for 2011-2015. Available at: http://osvita.ua/legislation/proftech/8836 (in Ukrainian)

[9] Kosyrev V.P. The continuous methodical training system of vocational training teachers. Dissertation for the degree of Doctor of the Pedagogical Sciences: 13.00.08. Moscow, 2007. (in Russian)

[10] Krivelyova A.A. Designing the psychological and pedagogical training of future teachers in vocational schools. Dissertation for the degree of Doctor of the Pedagogical Sciences: 13.00.04. Khmelnitsky, 2018. (in Ukrainian)

[11] Boyko A.M. (et al.) Methods of integrated course teaching and study "Theory and history of pedagogy". ISDO, Kyiv, 1996. (in Ukrainian)

[12] Nichkalo N.G. Development of professional education in conditions of globalization and integration processes. NPU M.P. Dragomanova, Kyiv, 2014. (in Ukrainian)

[13] Kremen V.G., Kovbasyuk Y.V. (et al.) (Eds.) Odult education: encyclopedic dictionary / under the editorship of. Osnova, Kyiv, 2014. (in Ukrainian)

[14] Dubaseniuk O.A. Professional-pedagogical education: contemporary conceptual models and development trends, ed. 2-e, dop. ZhDU im. I. Franka, Zhytomyr, 2008. (in Ukrainian)

[15] Stepanov O.M. Psychological encyclopedia. Akademvydav, Kyiv, 2006. (in Ukrainian)

[16] Sadova V.V. Fundamentalisation of the content of pedagogical disciplines in the future elementary school teachers' preparation process: theoretical and methodological aspects. Published by Kozlov R., Kryvyi Rih, 2016. (in Ukrainian)

[17] Tarkhan L.Z. Theoretical and methodological bases of didactic competence formation of future teachers of engineering. Dissertation for the degree of Doctor of the Pedagogical Sciences: 13.00.04. Kyiv. 2008. (in Ukrainian)

[18] Tytova N.M. Theoretical and methodological foundations of future vocational training teachers' psychological and pedagogical training. Dissertation for the degree of Doctor of the Pedagogical Sciences: 13.00.04. Kyiv, 2019. (in Ukrainian)

[19] Romantsev G.M., Fedorov V.A., Osipova I.V., Tarasyuk O.V. Level of vocational pedagogical education: theoretical and methodological bases of standardization. RHPPU, Ekaterinburg, 2011. (in Russian)

[20] Khomich L.O. Professional and pedagogical training of elementary school teachers. Master-S, Kyiv, 1998. (in Ukrainian)

[21] Batyshev S.Ya. (Ed.) Vocational education encyclopedia: in 3 volumes, vol. 2. APO, Moscow, 1999. (in Russian) 
[22] Orosová R., Starosta V., Petríková K., Diheneščíková L. Pedagogická a psychologická príprava budúcich učitelov (v podmienkach Univerzity P. J. Šafárika v Košiciach, Slovenská republika). Scientific Bulletin of Mukachevo State University. Pedagogy and Psychology series, 1 (7) (2018), 240-244. doi: 10.31339/2413-3329-2018-1(7)-240-244 (in Polish)

[23] Pérez-García P., Morales-Ocana A., Martin-Romera A., Garcia-Martinez I. Initial Training of Future Education Professionals: Are You Prepared for Inclusion? Paper ECER (2018). Available at: http://dx.doi.org/10.2139/ssrn.3253665 (in Spanish)

Address: Nataliya Tytova, Oksana Katsero, National Pedagogical Dragomanov University, 9, Pyrohova Str., 9, Kyiv, 01601, Ukraine;

Oksana Kondur, Vasyl Stefanyk Precarpathian National University, 57, Shevchenko Str., IvanoFrankivsk, 76018, Ukraine.

E-mail: titnat2008@ukr.net; o.katsero@gmail.com; oxikon13@gmail.com

Received: 28.01.2020; revised: 18.03.2020.

Титова Наталія, Кацеро Оксана, Кондур Оксана. Системний аналіз досвіду психолого-педагогічної підготовки майбутніх педагогів. Журнал Прикарпатського університету імені Василя Стефаника, 7 (1) (2020), 199-206.

У статті зазначено, що інтеграція вищої освіти України до європейського освітнього простору пов'язана з проблемами реформування системи професійної освіти відповідно до міжнародних вимог, тому актуальне системне дослідження загально педагогічної підготовки майбутніх вчителів та викладачів. Основним завданням вищої професійної освіти є підготовка вчителів, готових до організації та впровадження фундаментальної, технічної та професійної підготовки на практиці на всіх рівнях професійної освіти. Визначено, що ефективним способом реалізації вимог до професійних якостей майбутніх спеціалістів є диверсифікація їх професійної підготовки. Водночас важдивим $е$ створення та забезпечення умов для позитивної синергії з метою забезпечення науковості, послідовності, інноваційності, доступності, неперервності та різноманітності освіта для майбутніх педагогічних фахівців.

Здійснено аналіз сутності психолого-педагогічної підготовки педагогів, особливопрофесійного навчання, що грунтується на єдності педагогічної теорії та практики, контекстного навчання і виховання, спирається на закономірності й механізми педагогічної творчості. За резудьтатами проведеного аналізу встановлено, що основними принципами даної підготовки є: науковість, культуровідповідність, фундаментальність, гуманізація, системність. Запропоновано формувати структуру психолого-педагогічної підготовки майбутнього вчителя з трьох основних компонент: інваріантної, змінної, результативної. Ці складові наповнені відповідними навчальними контентами. Проаналізовано термінологічні аспектів психолого-педагогічної підготовки майбутніх фахівців у закдадах вищої освіти. 3 урахуванням сучасних вимог уточнено понять: "навчання", "професійно-технічна підготовка вчителів", “загально педагогічна підготовка" та "психодогопедагогічна підготовка майбутніх фахівців педагогічних закдадів".

Ключові слова: психолого-педагогічна підготовка, педагоги професійного навчання, вища освіта, професійна освіта. 